\title{
COMBINING ABILITY AND GENETIC COMPONENT ANALYSES FOR BARLEY GENOTYPES (Horduem vulgare, L.) UNDER STRESS AND NON-STRESS ENVIRONMENTS El-Seidy, E. H. ${ }^{1}$; M. A. El-Moselhey ${ }^{2}$ A. A. El-Gammaal ${ }^{1}$ and
} A.A. El-Naggar ${ }^{2}$

${ }^{1}$ Fac. Agric., Agronomy Dept., Tanta Univ., Egypt.

${ }^{2}$ Agric. Res. Centre, Ministry of Agric. and Land Reclamation.

\begin{abstract}
The aim of this study was to assess the variations amongeset a half diallel cross using eight varieties and or / lines for drought characters, estimating combining ability and genetic components. For this objective, the investigation was carried out at the Experimental Farm of Gemmeiza Agricultural Research Station during the two seasons 2007/2008 and 2008/2009, Eight diverse barley varieties and/or lines (Hordeum vulgare, L.) and $28 \mathrm{~F}_{1}$ 's were planted in two experiments. The first experiment was normally irrigated three times at tillering, elongation and heading stages. The second one irrigated only once at tillering stage. The main results can be summarized as follow ; the water stress treatment decreased the means of relative water content (RWC), total soluble solids (TSS), flag leaf angle (FLa), number of spikes/plant (NS/P), number of kernels/spike (NK/S), 100-kernel weight (100-KW) and grain yield/plant (GY/P) for parents and their hybrids. Irrigation mean squares were significant for all traits, Line 9 was the best combiner under both conditions and Giza 124, Line 5 and Giza 126 under stress and the combined analysis for grain yield, where the best hybrids were Giza 126 x Giza 123 and Giza 126 x Line 10 for earliness and Line $5 \times$ Line 6, Line $6 \times$ Line 4,Giza $126 \times$ Giza 123 and Line $10 \times$ Line 4 for grain yield at both conditions. The heritability estimates ranged from 0.022 for TSS under stress condition to 0.50 for NS/P under normal condition
\end{abstract}

Keywords: Hordeum vulgare, Drought, GCA, SCA, Stress, Water, Tolerance, Barley, Heritability.

\section{INTRODUCTION}

Drought is a major stress factor, which limits crop production in most area of the world. The rate at a water deficit develops can affect the nature, growth behavior and physiology of plant. The physiological and metabolic process may be affected by water stress, including growth, osmotic adjustment and photosynthesis (Morgan,1984).

Barley (Hordeum vulgare, L.) is not tolerated for prolonged or excessive drought. It will tolerate to soil moisture depletion to 30-35 percent of available moisture during grain formation and 10-20 percent near maturity. For optimum yield and quality, it is important to monitor soil moister condition regularly throughout the growing season and irrigation accordingly. Moisture stress at any stage of crop growth can cause an in reversible loss in yield potential. The severity of loss, depend up on many factors, timing, length and severity of the drought period. Moreover, yield reduction can be occurred due to the reversible effect in number of tillers, reduced kernel weights or fewer kernels. 
According to the experiment of (Rahman and Islam, 2004), the amount of water applied at each irrigation and how often a soil should be irrigated depend on several factors such as the degree of soil water deficit before irrigation, soil type, crops and climatic conditions. The major objectives of the present investigation therefore are; a) to assess the variations amongst a half diallel cross of eight barley varieties and/or lines for drought tolerance characters, b) determine the physiological traits that contribute tolerance for water deficit , c) identify quick but reliable indices of selection for tolerance to water deficit, d) to estimate gene action and the importance which should be given to this materials in a breeding program.

\section{MATERIALS AND METHODS}

This experiment was carried out at the Experimental Farm of Gemmeiza Agricultural Research Station, El-Gharbia Governorate, Egypt during the two successive seasons, 2007/08 and 2008/09. Eight barley varieties and /or lines (Horduem vulgare, L.) i.e; Giza-124 $\left(\mathrm{P}_{1}\right)$, Line-9 $\left(\mathrm{P}_{2}\right)$, Line-5 $\left(P_{3}\right)$, Line-6 $\left(P_{4}\right)$, Giza-126 $\left(P_{5}\right)$, Line-10 $\left(P_{6}\right)$, Giza-123 $\left(P_{7}\right)$ and Line-4 $\left(P_{8}\right)$ representing a wide range of diversity for several agronomic characters and drought resistance measurements were selected for this study.

In 2007/08 growing season, grains from each of the parental varieties and/or lines were sown at a various sowing dates in order to overcome the differences in time of heading. During this season, all possible parental combinations without reciprocals were made among eight parents giving a total of twenty-eight crosses.

In 2008/09 season, the eight parents and their twenty eight possible $F_{1}$ crosses were sown on $4^{\text {th }}$ December. Two adjacent experiments were conducted. The first experiment was irrigated three times at tillering, at elongation and at heading stages (favorable condition, $\mathrm{N}$ ) and the second one was irrigated only once at tillering stage (stress condition, S). Each experiment was designed in a randomized complete block design with three replications. Each plot consisted of two rows, 1.5 meters long with $30 \mathrm{~cm}$ between rows and plants within row were $15 \mathrm{~cm}$. apart allowing a total of 20 plants per plot. The dry method of sowing (Afir) was used in this concern. The other cultural practices of growing barley were practiced.

The following characters were recorded at $50 \%$ heading stage for ten guarded plants chosen randomly per row in each replicate: Relative water content (RWC \%), measured as described by Barrs and Weatherley(1962). Total soluble solids; values of the total soluble solids of the cell sap were obtained from the pressed sap of the (fourth upper leaf) of tested plants using the Abbe Refrectometer. Flag leaf angle (FLa): It was determined by using the protractor as well as Yield and some of its components; Number of spikes/plant (NS/P), Number of kernels/spike (NK/S), 100- kernel weight (g) and Grain yield /plant (g).

Drought susceptibility index (SI): It was calculated from genotype means for grain yield $(\mathrm{SI})$ using the generalized formula reported by Fisher and Maurer (1978). 


\section{Statistical analysis:}

The data of both experiments were subjected to proper statisical analysis of variance according to Snedecor and Cochran (1967). The combined analysis across the two experiments (stress and normal irrigation) were performed according to Cochran and Cox (1957). For comparason between means, Duncan's multiple range test was used, as proposed by Duncan (1955). General (GCA) and specific (SCA) combining ability estimates were obtained by employing Griffing (1956) diallel cross analysis designated as method 2 model 1 . Several genetic parameters were estimated according to Hayman (1954 a and b ) using diallel cross analysis.

\section{RESULTS AND DISCUSSION}

Analysis of variances: Mean squares of different barley genotypes for all studied characters in each environment and their combined data are presented in Tables (1 and 2). Statistical analysis revealed significant of irrigation treatments for all studied characters, indicating that the two irrigation regimes behaved differently for these characters.

In addition, mean squares due to genotypes were highly significant for all traits, providing evidence for presence of large amount of genetic variability, which considered adequate for further biometrical assessment. Significant differences for all traits were found among the parents at both conditions and their combined.

Meanwhile, significant differences of crosses mean squares were detected for all characters, reflecting the diversity of the parents for these studied characters, and that these diversity could be transmitted to the progenies. Also, mean squares of parents vs. crosses showed significant differences for all traits, indicating the presence of hybrid vigor of the studied barley genotypes .

For all traits, mean squares of genotypes $x$ environments interactions were significant, indicating that genotypes responded differently to water regime for these traits and reflecting the possibility of selecting the most tolerant genotypes. Mean squares of parents $x$ environments, crosses $x$ environment and parent vs. crosses $x$ environment were highly significant for most traits, revealing that the performance of parents and/or most crosses were changed from environment to another.

Mean performances of the eight parents and their $F_{1}$ at stress and normal irrigation as well as their combined data are presented for all the studied characters in Table (3). Data show that, the highest values for RWC were recorded by Line 6, Giza 126 and Giza 124 under two conditions and their combined. Also hybrids, Line $5 \times$ Line 4 and Line $5 \times$ Giza 126 observed the highest values at the two conditions and their combined. For TSS, the highest values belonged to Line 9, Line 5, Line 6 and Giza 126 at the two conditions and their combined analysis and to Giza 123 under stress and the combined data. Also crosses, Giza $124 \times$ Line 10, Line $9 \times$ Line 5, Line $5 \times$ Giza 123, Line $6 \times$ Giza 123 and Line $10 \times$ Giza 123 gave the highest values at the two conditions and their combined analysis. Normal condition had lower values than stress condition reached $-14.24 \%$. 
El-Seidy, E. H. et al.

1 
J. Plant Prod., Mansoura Univ. Vol. 1 (11), November, 2010

2

1455 
El-Seidy, E. H. et al.

In respect to FLa, the lowest values were detected for Line 5 at normal and for Giza 124 under stress and the combined analysis, Giza $124 \times$ Line 4 under both conditions and their combined and Giza $124 \times$ Giza 123 under stress condition. The reduction in flag leaf angle reached $35.07 \%$.

Table(3): Mean performances of eight barley genotypes and their $F_{1}$ crosses for relative water content, total soluble solids, flag leaf angle and susceptibility index under normal and stress conditions combined data.

\begin{tabular}{|c|c|c|c|c|c|c|c|c|c|c|}
\hline \multirow{2}{*}{ Genotypes } & \multicolumn{3}{|c|}{ RWC(\%) } & \multicolumn{3}{|c|}{ TSS } & \multicolumn{3}{|c|}{ FLa } & SI \\
\hline & $\mathbf{N}$ & $\mathrm{S}$ & Com & $\mathbf{N}$ & $\mathbf{S}$ & Com & $\mathbf{N}$ & $\mathbf{S}$ & Com & Com \\
\hline Giza124( $\left.p_{1}\right)$ & 89.66 & 83.67 & 86.66 & 16.67 & 18.67 & 17.67 & 31.66 & 23.33 & 27.50 & 0.11 \\
\hline Line-9( $\left.p_{2}\right)$ & 84.24 & 72.40 & 78.32 & 18.33 & 20.33 & 19.33 & 38.33 & 24.33 & 31.33 & 1.66 \\
\hline Line-5( $\left.p_{3}\right)$ & 86.30 & 78.03 & 82.17 & 18.67 & 21.67 & 20.17 & 30.00 & 28.00 & 29.00 & 0.85 \\
\hline Line6 $\left(p_{4}\right)$ & 95.22 & 83.04 & 89.13 & 19.00 & 22.00 & 20.50 & 43.33 & 23.67 & 33.50 & 2.14 \\
\hline $\operatorname{Giza126}\left(p_{5}\right)$ & 90.76 & 83.44 & 87.10 & 19.00 & 21.67 & 20.33 & 40.00 & 26.67 & 33.33 & 0.73 \\
\hline Line-10 $\left(p_{6}\right)$ & 86.58 & 77.02 & 81.79 & 17.67 & 19.67 & 18.67 & 35.00 & 24.67 & 29.83 & 0.19 \\
\hline Giza123( $\left.p_{7}\right)$ & 85.98 & 78.35 & 82.16 & 16.67 & 21.67 & 19.17 & 36.67 & 24.67 & 30.67 & 1.25 \\
\hline Line-4( $\left.p_{8}\right)$ & 85.00 & 76.98 & 80.99 & 18.00 & 20.00 & 19.00 & 36.67 & 22.67 & 29.67 & 1.29 \\
\hline Giza124x Line 9 & 87.76 & 84.45 & 86.11 & 18.33 & 21.00 & 19.67 & 41.67 & 31.67 & 36.67 & 0.82 \\
\hline$x$ Line 5 & 83.62 & 77.78 & 80.70 & 18.67 & 22.33 & 20.50 & 35.00 & 24.33 & 29.67 & 0.39 \\
\hline x Line6 & 87.58 & 72.54 & 80.06 & 18.33 & 20.33 & 19.33 & 39.33 & 33.33 & 36.33 & 0.48 \\
\hline x Giza126 & 92.15 & 77.33 & 84.74 & 18.67 & 20.00 & 19.33 & 37.00 & 22.00 & 29.50 & 1.69 \\
\hline$x$ Line 10 & 78.65 & 76.73 & 77.69 & 19.33 & 21.33 & 20.33 & 43.33 & 23.00 & 33.17 & 1.21 \\
\hline x Giza123 & 77.64 & 68.48 & 73.06 & 18.00 & 19.67 & 18.83 & 37.00 & 20.00 & 28.50 & 1.34 \\
\hline$x$ Line 4 & 85.06 & 68.33 & 76.69 & 16.33 & 19.00 & 17.67 & 28.33 & 22.00 & 25.18 & 0.58 \\
\hline Line $9 \times$ Line 5 & 86.32 & 73.79 & 80.05 & 19.00 & 21.33 & 20.17 & 35.00 & 29.33 & 32.17 & 0.21 \\
\hline & 85.31 & 82.75 & & 16.33 & 17.67 & & 35.00 & 24.33 & 29.67 & 1.32 \\
\hline x Giza126 & 82.59 & 70.50 & 76.54 & 18.00 & 20.33 & 19.17 & 51.67 & 27.33 & 39.50 & 1.17 \\
\hline$x$ Line 10 & & 64.51 & & 18.00 & 20.33 & 19.17 & 40.00 & 29.00 & 34.50 & 2.32 \\
\hline$x$ Giza123 & 83.62 & 73.23 & 78.42 & 18.33 & 21.00 & 19.67 & 35.00 & 26.00 & 30.50 & 1.89 \\
\hline$x$ Line 4 & 90.52 & 83.22 & 86.87 & 17.33 & 22.00 & 19.67 & 40.00 & 24.67 & 32.33 & 1.80 \\
\hline Line $5 \times$ Line6 & 96.32 & 75.75 & 86.04 & 18.67 & 20.33 & 19.50 & 53.33 & 27.00 & 40.17 & 1.08 \\
\hline x Giza126 & 95.42 & 85.89 & 90.66 & 18.67 & 20.67 & 19.67 & 41.67 & 23.33 & 32.50 & 2.41 \\
\hline$x$ Line 10 & 89.70 & 81.08 & 85.39 & 17.67 & 22.33 & 20.00 & 31.67 & 25.33 & 28.50 & 0.27 \\
\hline xGiza123 & 89.12 & 75.22 & 82.17 & 19.00 & 21.33 & 20.17 & 36.67 & 23.33 & 30.00 & 2.22 \\
\hline$x$ Line 4 & 92.87 & 82.77 & 87.82 & 17.67 & 22.33 & 20.00 & 55.00 & 24.67 & 39.80 & 1.42 \\
\hline Line6 x Giza126 & 84.46 & 79.33 & 81.89 & 18.67 & 21.33 & 20.00 & 36.67 & 25.33 & 31.00 & 2.08 \\
\hline $\mathrm{x}$ Line 10 & 84.48 & 80.66 & 82.57 & 17.33 & 20.67 & 19.00 & 40.00 & 30.67 & 35.33 & 1.02 \\
\hline xGiza123 & 81.89 & 80.66 & 81.28 & 20.00 & 21.33 & 20.67 & 41.67 & 25.00 & 33.33 & 0.22 \\
\hline X Line 4 & 85.75 & 82.14 & 83.95 & 17.67 & 19.33 & 18.50 & 46.67 & 25.00 & 35.83 & 1.49 \\
\hline Giza126xLine10 & 86.26 & 75.88 & 81.07 & 16.67 & 20.00 & 18.33 & 38.67 & 23.33 & 31.00 & 1.56 \\
\hline x Giza123 & 84.46 & 82.12 & 83.29 & 18.00 & 19.33 & 18.67 & 35.00 & 24.33 & 29.67 & 0.23 \\
\hline$x$ Line 4 & 87.03 & 79.36 & 83.19 & 18.00 & 21.33 & 19.67 & 36.00 & 24.67 & 30.33 & 2.05 \\
\hline Line10xGiza123 & 84.28 & 81.77 & 83.03 & 19.67 & 21.67 & 20.67 & 30.00 & 24.00 & 27.00 & 1.04 \\
\hline$x$ Line 4 & 86.92 & 79.07 & 82.99 & 17.67 & 20.33 & 19.00 & 40.00 & 25.67 & 32.83 & 1.05 \\
\hline Giza123 x Line4 & 86.29 & 84.02 & 85.15 & 17.00 & 19.33 & 18.17 & 45.00 & 21.00 & 33.00 & 2.17 \\
\hline Average & 86.92 & 78.18 & 82.52 & 18.08 & 20.66 & 19.37 & 38.83 & 25.21 & 32.02 & 0.92 \\
\hline L.S.D 5\% & 3.11 & 4.09 & 3.59 & 1.33 & 1.63 & 1.47 & 6.74 & 2.91 & 5.14 & - \\
\hline L.S.D 1\% & 4.13 & 5.44 & 4.78 & 1.76 & 2.17 & 1.96 & 8.97 & 3.86 & 6.83 & - \\
\hline Reduction & & 10.12 & & & 14.24 & & & 35.07 & & - \\
\hline
\end{tabular}

$\mathrm{N}=$ normal , $\mathrm{S}=$ stress, Com.= combined, $\mathrm{WUE}=$ water use efficiency and $\mathrm{SI}=$ susceptibility index 
Drought susceptibility index (SI) of all barley genotypes, which calculated for grain yield are presented in, Table (3). Results indicated that the barley parents, Giza 124, Line 5, Giza 126 and Line 10 gave the best desirable susceptibility to drought tolerance.

The susceptibility index for 28 crosses, indicated that the crosses of Giza 124 x Line 5, Giza $124 \times$ Line 6, Giza 124 x Line 4, Line 9 x Line 5, Line $5 \times$ Line 10, Line $6 \times$ Giza 123 and Giza $126 \times$ Giza 123 gave the best desirable susceptibility to drought tolerance. The superiority in the previous genotypes for drought tolerance may be due to high desirable for drought measure.

Yield and yield components:

It is clear from the data in Table (4) that water stress condition decreased the mean number of spikes per plant (NS/P), for the parents and hybrids. The highest NS/P belonged to Line 9 and Line 10 at the two conditions and their combined. While, Giza123 showed the smallest NS/P at the two conditions and their combined as well as Line 5 under water stress only. EL-Hawary (2000) and Abd El-Aty and El-Borhamy (2007) found significant differences among wheat genotypes in NS/P. The highest NS/P was obtained from the following crosses; Line $9 \times$ Line 5, Line $9 \times$ Line 6 , Line $9 \times$ Line 10, Line $9 \times$ Line 4 and Line $6 \times$ Line 10 at the two conditions and their combined. The reduction in NS/P reached $8.96 \%$.

With regard to number of kernels per spike (NK/S), the parents Line 5, Giza 126 and Line 6 showed the highest values at the two conditions and their combined while, Line 9 revealed lowest number of NK/S at the two conditions and their combined. Also crosses; Giza $124 \times$ Line 5, Giza $124 \times$ Giza 126, Line $6 \times$ Line 10, Line $6 \times$ Line 4 and Line $10 \times$ Line 4 showed the highest values at the two conditions and their

combined. While, Giza 126 x Line 4 , Line $10 \times$ Giza 123 and Giza $123 \times$ Line 4 showed the lowest values at the two conditions and their combined. Water stress treatment decreased the mean values of NK/S for parents and their hybrids by about $6.20 \%$. This reduction may be due to the effect of water deficit on pollination and fertilization processes, which lead to decreasing kernels per spike. Similar results were obtained by El-Hawary (2000), Mohammed (2001), Moursi (2003), Mohamed (2004) and Farhat (2005). In addition, several investigators reported that the reduction in NK/S was attributed to reducing seed set under water stress condition (Fisher and Maurer, 1978).

Results showed that the mean values of 100 - kernel weight (100-KW) for the parents and hybrids under water stress condition were lighter than that under normal condition. Moursi (2003) reported that the reduction of metabolites formation and its translocation from source to sink then 100-KW was depressed. These results agreed with those obtained by Mohammed (2001), Bayoumi (2004), Mohamed, Magda (2004) and Farhat (2005). With regard to the parents, the heaviest 100-KW were obtained from Giza 124 , Giza 126 and Giza 123 under the two conditions and their combined, while, the grains of Line 5 at the two conditions and their combined were the lightest. The heaviest 100-KW of barley hybrids were obtained from Line $10 \mathrm{x}$ 
El-Seidy, E. H. et al.

Giza 123 and Giza 123 x Line 4 under the two conditions and their combined. While, the lightest 100-kernel weight of barley crosses were relative to Line 5 $x$ Line 10 and Line $6 x$ Line 10 at the two conditions and their combined .The reduction in $100-\mathrm{KW}$ reached $1.94 \%$.

Table(4): Mean performances of eight barley genotypes and their $F_{1}$ crosses for number of spikes / plant, number of kernels / spike, 100 kernel weight and grain yield/plant under normal and stress conditions combined data.

\begin{tabular}{|c|c|c|c|c|c|c|c|c|c|c|c|c|}
\hline \multirow[t]{2}{*}{ Genotypes } & \multicolumn{3}{|c|}{\begin{tabular}{|c} 
Number of spikes / \\
plant
\end{tabular}} & \multicolumn{3}{|c|}{$\begin{array}{c}\text { No. of kernels / } \\
\text { spike }\end{array}$} & \multicolumn{3}{|c|}{$\begin{array}{c}100 \text { kernel weight } \\
(\mathrm{g})\end{array}$} & \multicolumn{3}{|c|}{$\begin{array}{c}\text { Grain yield/plant } \\
(\mathrm{g})\end{array}$} \\
\hline & $\mathrm{N}$ & $S$ & Com & $\mathrm{N}$ & $S$ & Com & $\mathrm{N}$ & $S$ & Com & $\mathrm{N}$ & $S$ & Com \\
\hline Giza124( $\left.p_{1}\right)$ & 13.0 & 12.2 & 12.5 & 66.0 & 66.0 & 66.0 & 6.00 & 5.39 & 5.52 & 33.07 & 32.53 & 32.80 \\
\hline Line-9 $\left(p_{2}\right)$ & & & & & & 58.0 & & & & & & \\
\hline$\left(p_{3}\right)$ & & 11.8 & & & & 74.0 & & 4.38 & 4.42 & & 27.03 & 26.13 \\
\hline Line6 $\left(p_{4}\right)$ & 2.7 & 12.0 & 12.4 & 72.0 & 8.0 & 70.0 & 5.29 & 4.61 & 4.95 & & & \\
\hline $\operatorname{Giza126}\left(p_{5}\right)$ & .7 & 11.8 & 11.8 & 70.0 & 70.0 & 70.0 & 5.56 & 5.38 & 5.47 & & 32.07 & 30.50 \\
\hline Line-10 $\left(p_{6}\right)$ & 5.5 & 15.4 & 15.5 & 66.0 & 68.0 & 67.0 & 4.77 & 4.56 & 4.66 & 31.32 & 32.17 & 31.75 \\
\hline Giza123 $\left(p_{7}\right)$ & & 9.9 & 10.8 & 70.0 & 66.0 & 68.0 & 5.54 & 5.52 & 5.53 & 28.28 & 23.19 & 5.74 \\
\hline Line-4( $\left.p_{8}\right)$ & & 11.5 & & 72.0 & & 69.0 & 5.25 & 4.78 & 5.02 & 33.32 & 27.12 & 30.22 \\
\hline $4 x$ Line 9 & & 11.4 & & 64.0 & & 65.0 & & 5.36 & 5.44 & & 27.41 & 29.24 \\
\hline & & 5 & & 72.0 & 0 & 70.0 & 56 & 5.47 & 5.52 & & 2030 & .16 \\
\hline & & 1.8 & & 66.0 & .0 & 66.0 & 5.60 & 5.62 & 5.61 & & 23.45 & \\
\hline & & .1 & & 74.0 & 3.0 & 70.0 & 5.39 & 5.57 & 5.48 & & 26.14 & 0.34 \\
\hline & & 11.2 & 11.4 & 60.0 & 54.0 & 57.0 & 5.57 & 5.55 & 5.56 & & 20.09 & 22.20 \\
\hline & & 10.0 & & 70.0 & 64.0 & 67.0 & 5.62 & 5.66 & 5.64 & & 24.97 & 27.94 \\
\hline & & 12.3 & & 56.0 & & 55.0 & 5.63 & 5.73 & 5.68 & & 17.71 & .51 \\
\hline & & & & & & 69.0 & & 5.33 & 5.39 & & 33.61 & \\
\hline & & 12.3 & & 68.0 & & 66.0 & .43 & 4.68 & 5.06 & & 22.30 & 90 \\
\hline & & 11.7 & & 70.0 & 64.0 & 67.0 & .41 & 5.42 & 5.42 & 34.01 & 28.29 & 1.15 \\
\hline & & 14.0 & 14.1 & 62.0 & 58.0 & 60.0 & 5.28 & 5.00 & 5.25 & & 24.14 & 30.16 \\
\hline & & 12.0 & & 66.0 & 60.0 & 63.0 & 5.43 & 5.00 & 5.38 & & 22.74 & 26.98 \\
\hline & & 12.2 & & 56.0 & 52.0 & 54.0 & 5.62 & 5.42 & 5.52 & & 24.19 & 28.40 \\
\hline & & 11.8 & & 68.0 & & 66.0 & 40 & 5.17 & 30 & & 28.88 & \\
\hline & & 11.5 & & 70.0 & & 67.0 & & 5.39 & 5.38 & & 24.27 & 72 \\
\hline & & 12.7 & 12.8 & 66.0 & 64.0 & 65.0 & 5.00 & 4.95 & 4.81 & & 24.98 & .50 \\
\hline & & 9.7 & & 66.0 & 62.0 & 64.0 & .65 & 5.54 & 5.60 & 33.84 & 23.02 & 3.40 \\
\hline & & 12.7 & & 56.0 & 54.0 & 55.0 & 5.55 & 5.37 & 5.46 & 23.24 & 18.51 & 0.87 \\
\hline x Giza126 & & 9.3 & 10.2 & 56.0 & 54.0 & 55.0 & 5.55 & 5.40 & 5.48 & 24.72 & 17.32 & 21.02 \\
\hline & & 14.4 & & 74.0 & 66.0 & 70.0 & 4.43 & 4.69 & 4.56 & 26.28 & 30.12 & 28.20 \\
\hline & & .5 & & 56.0 & 52.0 & 54.0 & 57 & 5.62 & 5.60 & & 21.22 & .89 \\
\hline & & & & 76.0 & & 73.0 & 49 & 5.24 & 5.37 & & 27.06 & 74 \\
\hline & & 12.3 & & 54.0 & 54.0 & 54.0 & 5.41 & 5.57 & 5.49 & 26.91 & 20.89 & .90 \\
\hline & & 11.2 & 11.2 & 68.0 & 66.0 & 67.0 & 5.62 & 5.43 & 5.52 & & 29.00 & .50 \\
\hline & & 11.8 & 11.4 & 54.0 & 54.0 & 54.0 & 5.70 & 5.52 & \begin{tabular}{|l|}
5.61 \\
\end{tabular} & 17.85 & 23.11 & 20.48 \\
\hline xGiza123 & 12.1 & 11.0 & 12.0 & 52.0 & 46.0 & 49.0 & 5.77 & 5.53 & 5.65 & 20.72 & 17.61 & 19.16 \\
\hline & 12.7 & 11.2 & 12.0 & 78.0 & 70.0 & 74.0 & 5.27 & 5.16 & \begin{tabular}{|l|}
5.22 \\
\end{tabular} & 31.22 & 26.49 & 28.86 \\
\hline $23 \times$ Line 4 & 11.5 & 10.5 & 11.0 & 54.0 & 36.0 & 45.0 & 5.86 & 5.63 & 5.74 & 17.99 & 12.38 & 15.18 \\
\hline & 12.9 & 11.8 & 12.0 & 65.4 & 61.4 & 63.4 & 5.39 & 5.28 & 5.33 & 28.97 & 24.80 & 6.89 \\
\hline & & 1.2 & 1.2 & 5.3 & 5.4 & 5.3 & 0.20 & 0.25 & 0.22 & 4.13 & 3.38 & 3.74 \\
\hline & & & & 7.1 & 7.2 & 7.1 & 0.27 & 0.33 & 0.30 & 5.49 & 4.50 & 4.96 \\
\hline & & 8.96 & & & 6.2 & & & 1.95 & & & 14.38 & \\
\hline
\end{tabular}


As a result of water stress condition, the average of grain yield/plant (GY/P) for parents and their hybrids was decreased. Several investigators reported that drought stress reduced photosynthesis and translocation rates and increased respiration, which reduced available assimilates for grain filling and finally decreased GY/P. Abd El-Aty and El-Borhamy (2007) found similar results. The highest GY/P were showed by Giza 124 and Line 10 under the two conditions and their combined, While, the lowest GY/P was obtained by Line 5 under normal and combined data, Line 6 and Giza 123 under water stress and combined analysis. The hybrids, Line $6 \times$ Line 4 , Line $9 \times$ Giza 126, Line $9 \times$ Line 5 and Line $5 \times$ Line 6 yielded more than the other crosses under the two conditions and their combined. While, Giza $124 \times$ Line 4and Giza $123 \times$ Line4 gave the lowest values under normal and combined analysis; Line $5 \times$ Line 4, Line $10 \times$ Giza 123 and Line 6 x Giza 126 under water stress and combined data. The highest GY/P of these parents and crosses could be attributed to the highest GY/P of Line 6 and Line 9, which may possessed the genes controlling in GY/P. The reduction in GY/P per plant reached $14.38 \%$.

Combining ability analysis: Combining ability implies the capacity of parent to produce good progenies when crossed with the other parent.

Analysis of variance for combining ability as out lined by Griffing (1956) method 2 model 1 in each environment as well as their combined for all the studied traits are presented in Tables (1 and 2). The results indicate that mean squares of general combining ability (GCA) and specific combining ability (SCA) were significant for all the studied traits under the two environments and their combined, except GCA for total soluble solids under stress condition indicating the presence of both additive and non additive types of gene effects in the genetic system controlling of these traits.

The ratios of GCA/SCA were greater than unity under the two environments and the combined analysis for all traits, except total soluble solids under stress and the combined analysis, flag leaf angle under normal. These results suggested predominant role of additive type of gene action for these traits and the potential for obtaining further improvements of these traits by using pedigree selection program. These results were coincident with those reported by Abd El-Aty and El-borhamy (2007).

The mean squares of interaction between environment and each of GCA and SCA were significant for all the studied traits, except GCA $\times$ Env, SCA x Env for total soluble solids, number of kernels/ spike, revealing that the magnitudes of different type of gene action were varied from one environment to another.

General combining ability effects: Estimates of GCA (ĝi) effects of all barley parental genotypes for each trait in combined data are presented in Table (5).Such effects are being used to compare the average performance of each parent with the other and facilitate selection of parents for further improvement to drought tolerance. 
El-Seidy, E. H. et al.

Table (5): Estimates of general combining ability effects for relative water content (RWC), total soluble solids (TSS), Flag leaf angle (FLA), number of spikes/plant (NS/P), number of kernels/spike (NK/S), 100 kernels wieght $(100 \mathrm{kw})$ and grain yield/plant (GY/P) in the combined data.

\begin{tabular}{|c|c|c|c|c|c|c|c|}
\hline Parent & RWC (\%) & TSS & FLa & NS/P & NK/S & $\begin{array}{c}100 \mathrm{KW} \\
(\mathrm{g})\end{array}$ & $\begin{array}{c}\text { GY/P } \\
(\mathrm{g})\end{array}$ \\
\hline Giza124(p $\left.p_{1}\right)$ & $1.23^{\star \star}$ & $-0.20^{\star \star}$ & $-1.421^{\star \star}$ & $-0.67^{\star *}$ & $1.13^{\star \star}$ & $0.20^{* *}$ & $0.53^{* *}$ \\
\hline Line-9 $\left(p_{2}\right)$ & $-1.92^{\star \star}$ & 0.02 & $0.979^{\star \star}$ & $1.13^{\star *}$ & $-1.08^{* *}$ & $-0.11^{\star \star}$ & $2.47^{\star \star}$ \\
\hline Line-5( $\left.p_{3}\right)$ & $-1.70^{\star \star}$ & 0.12 & 0.26 & 0.02 & $3.33^{\star *}$ & $-0.17^{\star \star}$ & $0.96^{\star \star}$ \\
\hline Line6 $\left(p_{4}\right)$ & $2.87^{* *}$ & $0.17^{\star \star}$ & $2.045^{\star \star}$ & $0.32^{\star \star}$ & $1.93^{\star *}$ & $-0.11^{\star *}$ & $-0.44^{\star *}$ \\
\hline Giza126(p & $0.80^{\star \star}$ & $0.24^{\star *}$ & 0.20 & $-0.83^{* *}$ & 0.33 & $0.13^{\star \star}$ & $0.62^{\star \star}$ \\
\hline Line-10 $\left(\mathrm{p}_{6}\right)$ & $-0.97^{\star \star}$ & $-0.20^{\star *}$ & $-0.621^{\star \star}$ & $0.86^{\star *}$ & $-0.78^{\star \star}$ & $-0.21^{\star \star}$ & -0.05 \\
\hline $\operatorname{Giza123}\left(p_{7}\right)$ & $-1.32^{\star *}$ & $0.30^{\star *}$ & $-1.487^{\star \star}$ & $-0.76^{* *}$ & $-2.58^{* *}$ & $5.22^{* *}$ & $-2.24^{* *}$ \\
\hline Line-4(p $\left.p_{8}\right)$ & $1.02^{\star \star}$ & $-0.46^{\star *}$ & & -0.07 & $-2.28^{* *}$ & $5.06^{\star *}$ & $-1.85^{\star \star}$ \\
\hline LSD 0.05 & 0.30 & 0.12 & 0.43 & 0.10 & 0.44 & 0.02 & 0.31 \\
\hline LSD 0.01 & 0.40 & 0.16 & 0.57 & 0.13 & 0.59 & 0.03 & 0.41 \\
\hline L.S.D (gi-gj)5\% & 0.57 & 0.23 & 0.81 & 0.19 & 0.84 & 0.04 & 0.59 \\
\hline L.S.D (gi-gj) $1 \%$ & 0.76 & 0.31 & 1.08 & 0.25 & 1.12 & 0.05 & 0.78 \\
\hline
\end{tabular}

GCA (ĝi) in this study were found to be significantly differed from zero in all traits. High positive values would be highly appreciated under all the studies traits, except flag leaf angle where high negative effects would be useful from the breeder's point of view. It could be concluded that the parent Giza $123\left(p_{7}\right)$ followed by Giza 124 were the best combiners for FLa, indicating that these varieties considered as a good tolerant combiner for drought.

With respect to the traits, which the positive direction are interested, two parents (line 9 and Line 10) for number of spikes/plant, three parents (Giza 124, Line 5 and Line 6) for number of kernels /spike, four parents (Giza 124, Giza 126 and Giza 123) and Line 4 for 100 kernels weight and three parent (Line 9, Giza 126 and Giza 124) for grain yield/plant. Therefore, the two parents Giza 124, Giza 123 and Line 9 could be considered as excellent parents in breeding programs aimed to release parents to drought tolerance.

\section{Specific combining ability effects (Sij):}

SCA (Sij) of the parental combinations computed for seven traits in combined analysis are presented in Table (6). In the combined analysis; significant positive SCA effects were found in the crosses ; Line $5 \times$ Line 4 followed by, Line 6 x Giza 126; Line 9 x Giza 126, Line $10 \times$ Giza 123, Giza $124 \times$ Giza 126 and Giza 124 x Line 6 for RWC and crosses; Giza 124 x Line 6, Giza 124 x Line 5, Giza 124 x Giza 126, Line 6 x Line 4, Line 9 x Line 10, Line $9 \times$ Line 5, Line $6 \times$ Line 10 and Line $10 \times$ Line 4 for TSS. Significant negative SCA effects were detected in five parental combinations for flag leaf angle. The best crosses were Giza $124 \times$ Line 4 and Line $9 \times$ Line 6 . Highly significant positive SCA effects were found in the crosses; Line $6 \times$ Giza 123, Line $9 \times$ Line 5, Line $6 \times$ Line 10 and Line $5 \times$ Line 6 for NS/P, two crosses Line $10 \times$ Line 4 and Line $6 \times$ Line 4 gave the highest $\mathrm{Sij}$ effects for NK/S, thirteen crosses for 100-KW, the best crosses were Line $9 \times$ Line 5, Line $10 x$ Giza 123, Giza 124 x Line 10, Line 9 x Line 4 , Line 5 x Line 4 and Giza 126 x 
Line 10 for this trait and ten parental combinations for GY/P, the best crosses were Line 6 x Line 4, Giza 126 x Giza 123, Line 5 x Line 6, and Line $10 \times$ Line 4, Line $5 \times$ Giza 123 and Line $9 \times$ Line 5 for this trait.

Table (6) : Estimates specific of combining ability (SCA) effects for relative water content (RWC), total soluble solids (TSS), Flag leaf angle (FLA), number of spike/plant (NS/P), number of kernels/spike (NK/S), 100 kernels wieght (100 kw) grain yield/plant (GY/P) in the combined data.

\begin{tabular}{|c|c|c|c|c|c|c|c|}
\hline crosses & RWC (\%) & TSS & FLa & NS/P & NK/S & $\begin{array}{c}100 \mathrm{KW} \\
(\mathrm{g})\end{array}$ & $\begin{array}{c}\text { GY/P } \\
(\mathrm{g})\end{array}$ \\
\hline Giza124x Line 9 & $-3.51^{\star *}$ & 0.12 & $5.1^{* \star}$ & $-1.0^{\star \star}$ & 1.53 & 0.02 & -0.65 \\
\hline x Line 5 & 0.11 & $0.857^{*}$ & -1.19 & $-1.4^{\star \star}$ & 2.13 & $0.16^{\star *}$ & 0.78 \\
\hline x Line6 & $2.51^{\star \star}$ & $1.14^{\star \star}$ & $3.7^{\star \star}$ & 0.40 & -0.47 & $0.19^{\star *}$ & $-2.66^{\star \star}$ \\
\hline x Giza126 & $2.55^{\star \star}$ & $0.91^{* *}$ & -1.10 & $-0.97^{\star \star}$ & $5.13^{\star \star}$ & $-0.2^{\star \star}$ & $2.29^{\star *}$ \\
\hline $\mathrm{x}$ Line 10 & -0.98 & -0.33 & $3.2^{* \star}$ & $-1.2^{\star \star}$ & $-6.767^{\star \star}$ & $0.25^{\star *}$ & $-5.17^{\star \star}$ \\
\hline x Giza123 & -0.27 & -0.33 & -0.61 & 0.30 & $5.033^{\star *}$ & $-0.11^{*}$ & $2.76^{\star \star}$ \\
\hline$x$ Line 4 & $-3.78^{\star *}$ & 0.27 & $-5.5^{\star *}$ & $0.93^{\star *}$ & $-7.267^{\star *}$ & 0.09 & $-7.07^{\star \star}$ \\
\hline Line 9 x Line 5 & $1.79^{*}$ & $0.97^{* *}$ & -1.10 & $1.01^{* \star}$ & $3.333^{* *}$ & $0.34^{* *}$ & $2.8^{\star *}$ \\
\hline$x$ Line 6 & $-3.41^{\star \star}$ & -0.24 & $-5.4^{\star \star}$ & -0.30 & 1.73 & -0.05 & $-4^{\star \star}$ \\
\hline x Giza126 & $3.35^{\star \star}$ & -0.31 & $6.3^{\star \star}$ & $-0.64^{*}$ & $4.33^{\star \star}$ & 0.06 & 1.17 \\
\hline $\mathrm{x}$ Line 10 & $1.94^{*}$ & $1.12^{\star *}$ & 2.12 & -0.20 & -1.57 & $0.25^{\star *}$ & 0.86 \\
\hline x Giza123 & $-6.22^{\star \star}$ & $-0.88^{*}$ & -1.01 & -0.10 & $3.23^{*}$ & -0.06 & 0.14 \\
\hline$x$ Line 4 & $-4.92^{\star *}$ & $-1.276^{*}$ & -0.71 & 0.20 & $-6.07^{* *}$ & $0.24^{* *}$ & 0.90 \\
\hline Line 5 x Line6 & 0.34 & $-2.68^{* *}$ & $5.8^{* *}$ & $0.86^{\star \star}$ & $-2.67^{*}$ & $0.25^{\star *}$ & $4.12^{\star \star}$ \\
\hline x Giza126 & $-5.07^{* *}$ & -0.58 & 0.02 & 0.50 & -0.07 & 0.08 & $2.25^{\star}$ \\
\hline $\mathrm{x}$ Line 10 & $-2.99^{\star \star}$ & -0.14 & $-3.2^{\star \star}$ & -0.50 & -0.97 & $-0.14^{*}$ & $-2.31^{\star \star}$ \\
\hline xGiza123 & -1.08 & -0.14 & -0.80 & -0.21 & -0.17 & $0.21^{* *}$ & $2.83^{* \star}$ \\
\hline$x$ Line 4 & $5.04^{\star \star}$ & 0.62 & $7.5^{\star \star}$ & 0.41 & $-9.47^{* \star}$ & $0.24^{\star \star}$ & $-5.13^{\star \star}$ \\
\hline Line6 x Giza126 & $4.48^{* *}$ & 0.04 & $-3.3^{\star *}$ & $-1.7^{\star \star}$ & $-10.67^{* *}$ & 0.13 & $-6.05^{\star *}$ \\
\hline $\mathrm{x}$ Line 10 & 0.98 & $0.97^{\star *}$ & 1.89 & $0.97^{\star *}$ & $5.43^{\star \star}$ & $-0.5^{\star *}$ & $1.79^{*}$ \\
\hline xGiza123 & $-1.89^{*}$ & 0.31 & 0.75 & $1.14^{* *}$ & $-8.77^{* *}$ & $0.16^{* *}$ & $-3.32^{* *}$ \\
\hline X Line 4 & 1.42 & $0.91^{* *}$ & 1.72 & 0.17 & $9.93^{\star \star}$ & 0.08 & $6.14^{\star \star}$ \\
\hline Giza126xLine10 & 0.23 & -0.43 & -0.60 & 0.201 & $-8.97^{\star *}$ & $0.24^{* *}$ & $-3.56^{\star \star}$ \\
\hline x Giza123 & -0.74 & $0.74^{\star}$ & -1.06 & 0.44 & $5.83^{\star \star}$ & $-0.2^{* *}$ & $4.23^{\star *}$ \\
\hline$x$ Line 4 & -0.38 & -0.66 & -1.93 & -0.032 & $-7.47^{\star \star}$ & 0.08 & $-5.18^{\star \star}$ \\
\hline Line10xGiza123 & $3.07^{* \star}$ & $-0.83^{*}$ & $-2.91^{*}$ & $-0.9^{\star \star}$ & $-11.07^{* *}$ & $0.31^{* *}$ & $-5.43^{\star *}$ \\
\hline x Line 4 & 0.63 & $0.94^{* *}$ & 1.39 & $-1.2^{\star \star}$ & $13.63^{* *}$ & 0.03 & $3.87^{* \star}$ \\
\hline Giza123 x Line4 & 0.79 & -0.23 & $2.42^{*}$ & -0.534 & $-13.57^{\star *}$ & $0.13^{*}$ & $-7.61^{\star \star}$ \\
\hline L.S.D(sij)5\% & 1.63 & 0.67 & 2.33 & 0.54 & 2.41 & 0.10 & 1.69 \\
\hline L.S.D(sij)1\% & 2.17 & 0.89 & 3.10 & 0.71 & 3.24 & 0.14 & 2.25 \\
\hline L.S.D (sij-sik) $5 \%$ & 2.41 & 0.99 & 3.45 & 0.80 & 3.57 & 0.15 & 2.51 \\
\hline L.S.D (sij-sik)1\% & 3.21 & 1.31 & 4.58 & 1.06 & 4.74 & 0.20 & 3.33 \\
\hline
\end{tabular}

Generally the best parental combinations were ; Line $9 \times$ Line 5, Giza $126 \times$ Giza124, Line $6 \times$ Line 10 and Line $10 \times$ Line 4 for most studied traits. These crosses could be successfully need for breeding to drought tolerant in barley. The results obtained herein concerning general and specific combining ability effects indicated that the excellent hybrid combinations were obtained from the three possible combinations between the parents of 
high and low general combining ability effects i.e. high $\mathrm{x}$ high, high $\mathrm{x}$ low and low $x$ low. Consequently it could be concluded that general combining ability effects of the parental lines were generally unrelated to the specific combining ability effects of their respective crosses.

\section{Genetic Components and Heritability}

The computed parameters for all traits under normal and water stress conditions are presented in Tables (7 and 8). Data show that, the additive component (D) was significant for all the studied traits under the two conditions, except for FLa under normal and water stress conditions; NK/S and GY/P under normal condition and for TSS under stress condition. These results indicated that the suggested predominant role of additive gene effects in the inheritance of these traits under normal and water stress conditions.

Highly significant values for the dominance component $\left(\mathrm{H}_{1}\right)$ was obtained for all traits under normal and water stress conditions. Values of $\left(\mathrm{H}_{1}\right)$ were higher in magnitude than the respective (D) ones for all traits at the two conditions. These results indicate that dominance type of gene action was the most prevalent genetic component for these traits. The contradiction in magnitude obtained between (D) and GCA estimate for some traits could be attributed to the great role of both allelic and non allelic genetic types of the expression for some traits under the two conditions. These results are in line with those reported by Polok et al. (1997) and Afify(2005).

Highly significant values for the dominance components $\left(\mathrm{H}_{2}\right)$ were obtained for all traits under normal and water stress conditions. Theoretically $\left(H_{2}\right)$ should be equal to or less than $\left(H_{1}\right)$ (Hayman, 1954b). In this study the values of $\mathrm{H}_{2}$ were smaller than the values of $\mathrm{H}_{1}$ for all traits under both conditions. This result indicates that the positive $(u)$ and negative $(v)$ alleles frequencies at the loci for the previous cases in question are not equal in preparation in the parents.

Insignificant $h^{2}$ values were detected for all studied traits under normal and water stress conditions, except for $100-\mathrm{KW}$ in both conditions as well as for GY/P under stress condition. Thus indicating that the effect of dominance was due to heterozygosity and that dominance was unidirectional appreciable heterotic effect for the exceptional cases. The same trend was obtained by Ahmed et al. ( 1998 ) and Moustafa (2002).

The covariance of additive and dominance ( $F$ ) was insignificant for all studied traits under both conditions, except for RWC and TSS under stress and normal conditions, respectively, NS/P under both conditions and $100-\mathrm{KW}$ under water stress conditions. Generally it could be concluded that unequality of the relative frequencies of dominant and recessive alleles in the parents for the exceptional cases. These findings were in line with those reached by Moustafa (2002).

The relative size of $(D)$ and $\left(H_{1}\right)$ estimated as $\left(H_{1} / D\right)^{1 / 2}$ can be used a weight measure of the average degree of dominance at each locus. The presence of over dominance for all studied traits under normal and water stress conditions. The same trend was obtained by Ahmed et al. ( 1998 ) and Afify ( 2005 ). 
J. Plant Prod., Mansoura Univ. Vol. 1 (11), November, 2010

7

1463 
The average frequency of negative vs. positive alleles in parental population was detected by computing the ratio of $\left(\mathrm{H}_{2} / 4 \mathrm{H}_{1}\right)$. Value largely deviating from one quarter were obtained for most traits under the two conditions, indicating that negative and positive alleles were unequally distributed among the parents, Tables (7 and 8).

The ratio of dominance $(K D) /$ recessive $(K R)=\left[\left(\begin{array}{ll}4 & \mathrm{DH} 1\end{array}\right)\right.$ $\left.\frac{1}{2}+\mathrm{F} /(4 \mathrm{DH} 1)^{\frac{1}{2}}-\mathrm{F}\right]$ were more than unity for all the studied traits under normal and water stress conditions. These results showed that the proportions of dominant alleles are greater in the parents than the recessive ones for all the studied traits under normal and water stress conditions. These results are in agreement with those obtained by El-Hosary et al, (1992), El-Marakby et al. ( 1994 ) and Ahmed et al. (1998).

Table (8): Genetic components of variation and proportions in diallel crosses for number of kernels/spike, 100 kernels weight and grain yield/plant under normal and stress conditions.

\begin{tabular}{|c|c|c|c|c|c|c|}
\hline \multirow{2}{*}{\begin{tabular}{|l|} 
Genetics \\
component
\end{tabular}} & \multicolumn{2}{|c|}{ NK/S } & \multicolumn{2}{|c|}{$100-K W(g)$} & \multicolumn{2}{|c|}{ GY/P (g) } \\
\hline & NS & $\mathbf{S}$ & NS & $\mathrm{S}$ & NS & $\mathbf{S}$ \\
\hline${ }^{\wedge} \mathbf{D}$ & $13.35 \pm 11.87$ & $40.56^{\star *} \pm 14.48$ & $0.23^{\star \star} \pm 0.07$ & $0.18^{\star *} \pm 0.03$ & $10.38 \pm 8.53$ & $13.64^{*} \pm 6.42$ \\
\hline${ }^{\wedge} \mathrm{H}_{1}$ & $257.59^{\star *} \pm 27.29$ & $175.72^{\star \star} \pm 33.29$ & $0.48^{* *} \pm 0.16$ & $0.36^{\star *} \pm 0.07$ & $25.33^{\star \star} \pm 19.6$ & $94.43^{\star *} \pm 14.76$ \\
\hline${ }^{n} \mathrm{H}_{2}$ & $196.72^{\star \star} \pm 23.74$ & $144.48^{\star \star} \pm 28.96$ & $0.39^{\star \star} \pm 0.14$ & $0.30^{\star \star} \pm 0.06$ & $00.77^{\star \star} \pm 17.06$ & $75.87^{\star \star} \pm 12.84$ \\
\hline${ }^{n} h^{2}$ & $18.01 \pm 15.92$ & $6.81 \pm 19.42$ & $0.33^{\star \star} \pm 0.09$ & $0.59^{\star \star} \pm 0.04$ & $20.90 \pm 11.44$ & $54.05^{\star *} \pm 8.61$ \\
\hline${ }^{\wedge} \mathbf{F}$ & $7.65 \pm 28.05$ & $45.58 \pm 34.21$ & $0.27 \pm 0.16$ & $0.17^{\star} \pm 0.07$ & $20.28 \pm 20.16$ & $22.34 \pm 15.18$ \\
\hline${ }^{\wedge} \mathbf{E}$ & $3.82 \pm 3.96$ & $3.97 \pm 4.83$ & $0.005 \pm 0.02$ & $0.008 \pm 0.01$ & $2.11 \pm 2.84$ & $1.40 \pm 2.14$ \\
\hline$(\mathrm{H} 1 / \mathrm{D})^{1 / 2}$ & 4.39 & 2.08 & 1.45 & 1.40 & 3.48 & 2.63 \\
\hline $\mathrm{H}_{2} / 4 \mathrm{H}_{1}$ & 0.19 & 0.21 & 0.20 & 0.21 & 0.20 & 0.20 \\
\hline $\mathrm{KD} / \mathrm{KR}$ & 1.14 & 1.74 & 2.37 & 2.00 & 1.78 & 1.90 \\
\hline $\mathrm{h}^{2} / \mathrm{H}_{2}$ & 0.09 & 0.05 & 0.84 & 1.96 & 0.21 & 0.71 \\
\hline Heritability & 0.39 & 0.25 & 0.19 & 0.28 & 0.21 & 0.20 \\
\hline$r$ & -0.15 & 0.33 & $-0.84^{* *}$ & $-0.88^{\star \star}$ & 0.03 & $0.64^{\star \star}$ \\
\hline $\mathbf{R}^{2}$ & 0.02 & 0.11 & 0.70 & 0.78 & 0.00 & 0.41 \\
\hline
\end{tabular}

*and"*indicate significant at 0.05 and 0.01 levels of probability, respectively NS= non stress and $\mathrm{S}=$ stress

The correlation coefficient value between parental mean $(\mathrm{Yr})$ and $(\mathrm{wr}$ + vr) for each array was significant positive for number of spikes per plant under normal and water stress conditions; TSS under normal as well as for grain yield per plant under water stress condition, indicating that decreases genes were dominant over increases. However, significant negative correlation values were obtained for FLa and $100-\mathrm{KW}$ in both conditions, RWC and TSS under water stress, indicating that increasing genes were recessive alleles over decreases. For other studied traits, low correlation value which could not be fruitful in getting any idea about the direction of dominance were obtained. Such low value of correlation coefficient might be due to the presence of epistasis and to additively of most genes involving the system in these traits. Also, it might reveal that high performance for such traits was controlled by dominant and recessive genes. These results are in agreement with those obtained by Eshghi and Akhundova(2009).

Heritability values: Heritability estimates in narrow sense for all traits under normal and water stress conditions are given in Tables (7 and 8). The heritability estimates ranged from 0.022 for TSS under stress condition to 
0.50 for NS/P under normal condition. Moderate heritability estimates were also shown for NS/P under normal condition. Low heritability estimates were detected for FLa, NK/S, 100-KW and GY/P under the two conditions as well as for TSS under normal and RWC under water stress condition indicating that most of the genetic variance may be due to non-additive genetic effect. These findings supported the previous results of genetic components, where the $\mathrm{H} 1$ estimates were found to have great role in these traits, Tables ( 7 and 8). Therefore the bulk method program for most traits might be quite promising. The same trend was reported by Moustafa (2002), Abd-El-Aty and El-Borhamy(2007) and Eshghi and Akhundova (2009).

\section{REFERENCES}

Abd El-Aty, M. S. M. and H. S. El-Borhamy (2007). Estimates of combining ability and susceptibility index in wheat diallel crosses under stress and normal irrigation treatments. Egypt. J. Plant Breed. 11(2): 651-667.

Afify, H.A. A. (2005). Study of genetic performance for some characters of hull less barley, Thesis. Fac.,(Agronomy-Crop Breeding) Agric., AlAzhar,Univ.,Egypt.

Ahmed, I. A.; A. M. El-Sherbini; A.M.O. El-Bawab; M.A. El-Moselhy and E.M. Salem (1998). Diallel analysis for yield and yield component in barley. Agric .Sci. Mansoura Univ 22(7):2971-2979.

Barrs, H.D.; and P.E. Weatherley (1962).Arc-examination of the relative turgidity technique estimating water deficts in leaves.Asut.J.Biol.Sci.15:413-428.

Bayoumi, T. Y. (2004). Diallel cross analysis for bread wheat under stress and normal irrigation treatments. Zagazig J. Agric. Res., 31 (2): 435455.

Cochran, W. G. and G. M. Cox (1957). Experimental Design, $2^{\text {nd }}$ ed. John Wiley, N.Y. USA. 611p.

Duncan, B. D. (1955). Multiple range and multiple F.test. Biometrics, 11:1-42.

EL-Hawary, M. A. (2000). Evaluation of some wheat varieties under water deficit conditions. Zagazig J.Agric,Res.,27(4): 819-830.

El-Hosary, A. A., M. A. Mahrous and A. A. Abul-Naas (1992). Genetical studies in barley (Hordeum vulgare L.) for earliness, some growth attributes and yield. Egypt. J. Agron., 17 (1-2): 15-26.

El-Marakby, A.M., R.A. Abo El-Enein., M. Yasicn and A.A. Mahmoud (1994 ).Genetic behavior and heritability estimates of some quantitative traits in diallel crosses of six rowed barley (Hordeum vulgare L.) .Egyptian J.(19).No.(1-2) 1-17.

Eshghi, R. and E. Akhundova(2009). Genetic analysis of grain yield and some agronomic traits in hulless barley. Fac., Genet., and Darvin., Baku State. Univ. Azerbaijan.

Farhat, W.Z.E. (2005). Genetical studies on drought tolerance in bread wheat (Triticum aestivum L). M.Sc. Thesis, Tanta Uni., Egypt.

Fisher, R.A. and R. Maurer (1978). Drought resistance in spring wheat cultivars I.Grain yield responses.Aust.J.Agric.Res.,29:897-912.

Griffing, J.B.(1956).Concept of general and specific combining ability in relation to diallel crossing system.Aust.J.Biol.Sci.9:463-493.

Hayman. B.I. (1954a). The analysis of variance of diallel tables. Biometerics. 10: $235-244$.

Hayman. B.I. (1954b). The theory and analysis of diallel crosses Genetics. 39: $789-809$. 
Mohamed, Magda, E. A. (2004). Genetical analysis and evaluation of drought tolerance trait under different conditions in wheat (Triticum aestivum L). Ph. D. Thesis, Tanta Univ., Egypt.

Mohammed, I A. E. I. (2001). Breeding studies on drought tolerance in bread wheat (Triticum aestivum L). M. Sc. Thesis, Zagazig Univ., Egypt.

Morgan,J.M.(1984).Osmoregulation and water stress in highest plants Ann. Rev.Plant physiol. $35: 299-319$.

Moursi, A.M. (2003). Performance of grain yield for some wheat genotypes under stress by chemical desiccation. Ph. D. Thesis, Zagazig Univ., Egypt.

Moustafa, Kh. A. (2002). Diallel cross analysis of some quantitative traits in barley. Zagazig J. Agric. Res., 29 (4): 1069-1079.

Polok, K., I. Szarajko and M.Maluszynsld ( 1997 ). Barley mutant heterosis and fixation of Fl-performance 'in doubled haploid lines. Plant Breeding. 116:2,133-140.

Rahman, S.M. and A. Islam, (2004). Yield and water relation as influenced by irrigation and depth of tillage. (C.F. Springer Link- www.springlink.com).

Snedecor, G. and W. G. Cochran (1967). Statistical Methods.6 $6^{\text {th }}$ ed., lowa state Univ. Press, Ames, lowa, USA.

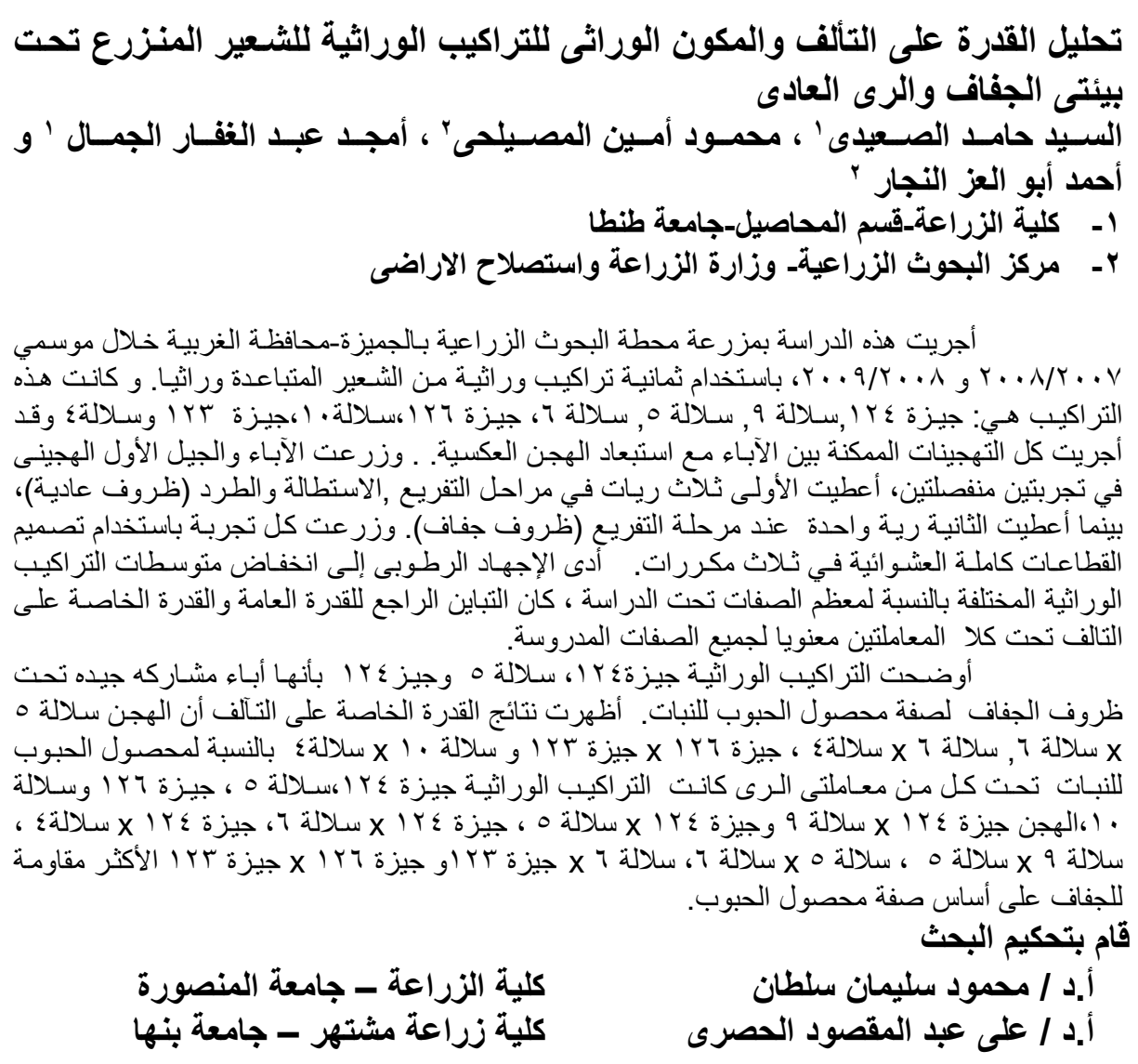


J. Plant Prod., Mansoura Univ. Vol. 1 (11), November, 2010 

Table (2): Mean square of ordinary analysis for number of spikes/plant, number of kernels/spike, 100 kernels weight and grain yield/plant under normal and stress conditions as well as the combined data.

\begin{tabular}{|c|c|c|c|c|c|c|c|c|c|c|c|c|c|c|}
\hline \multirow{2}{*}{ S.0.V } & \multirow{2}{*}{ df } & \multirow{2}{*}{$\begin{array}{c}\text { df } \\
\text { Com. }\end{array}$} & \multicolumn{3}{|c|}{ NS/P } & \multicolumn{3}{|c|}{ NK/S } & \multicolumn{3}{|c|}{$100-K W(g)$} & \multicolumn{3}{|c|}{ GY/P (g) } \\
\hline & & & NS & $\mathbf{S}$ & Com & NS & $\mathbf{S}$ & Com & NS & $\mathbf{S}$ & Com & NS & $\mathbf{S}$ & Com \\
\hline Replication & 2 & & 1.49 & 1.50 & & 9.33 & 0.33 & & 0.008 & 0.067 & & 3.89 & 0.75 & \\
\hline Environments & & 1 & & & $72.42^{\star \star}$ & & & $888.17^{\star}$ & & & $2.593^{\star \star}$ & & & $936.61^{* *}$ \\
\hline \begin{tabular}{|l|} 
Rep.with \\
environment
\end{tabular} & & 4 & & & 1.50 & & & 4.83 & & & 0.04 & & & 2.32 \\
\hline Genotypes & 35 & & $6.32^{\star \star}$ & $5.93^{\star \star}$ & $10.58^{\star \star}$ & $166.36^{\star \star}$ & $180.91^{\star \star}$ & $327.21^{\star \star}$ & $0.39^{\star \star}$ & $0.38^{\star \star}$ & $0.69^{\star *}$ & $86.63^{\star \star}$ & $68.12^{\star \star}$ & $124.04^{\star \star}$ \\
\hline Parents & 7 & & $9.65^{\star \star}$ & $7.99^{\star \star}$ & $16.09^{\star \star}$ & $85.50^{* *}$ & $59.79^{*}$ & $128.14^{\star \star}$ & $0.69^{\star \star}$ & $0.57^{* *}$ & $1.13^{\star \star}$ & $37.46^{\star *}$ & $45.10^{\star \star}$ & $41.77^{\star \star}$ \\
\hline Crosses & 27 & & $5.50^{\star \star}$ & $5.28^{\star \star}$ & $9.03^{\star \star}$ & $176.94^{\star \star}$ & $192.0^{\star \star}$ & $348.02^{\star \star}$ & $0.25^{\star \star}$ & $0.21^{\star \star}$ & $0.40^{\star \star}$ & $97.66^{\star \star}$ & $64.28^{\star \star}$ & $133.54^{\star *}$ \\
\hline Pvs.C & 1 & & $5.08^{\star}$ & $8.97^{*}$ & $13.77^{\star \star}$ & $446.88^{* \star}$ & $729.17^{\star \star}$ & $1158.86^{\star \star}$ & $2.01^{\star \star}$ & $3.65^{\star \star}$ & $5.53^{\star \star}$ & $133.02^{\star \star}$ & $333.18^{\star \star}$ & $443.63^{* *}$ \\
\hline Genotypes x Env. & & 35 & & & $1.67^{\star \star}$ & & & $20.05^{\star}$ & & & $0.08^{\star \star}$ & & & $30.71^{* *}$ \\
\hline Parents x Env. & & 7 & & & 1.55 & & & 17.14 & & & $0.14^{\star \star}$ & & & $40.79^{\star \star}$ \\
\hline Crosses $x$ Env. & & 27 & & & $1.75^{\star *}$ & & & $20.91^{*}$ & & & $0.06^{\star *}$ & & & $28.40^{* *}$ \\
\hline P v s .C x Env. & & 1 & & & 0.28 & & & $17.2^{*}$ & & & $1.12^{\star \star}$ & & & $22.58^{* *}$ \\
\hline Error & 70 & 140 & 0.526 & 0.55 & 0.54 & 10.705 & 10.96 & 10.83 & 0.015 & 0.023 & 0.019 & 6.39 & 4.29 & 5.34 \\
\hline GCA & 7 & & $6.60^{\star \star}$ & $5.58^{\star \star}$ & $10.98^{\star \star}$ & $34.63^{\star \star}$ & $56.89^{\star \star}$ & $84.8^{\star \star}$ & $0.31^{\star \star}$ & $0.32^{\star \star}$ & $0.60^{\star \star}$ & $28.94^{\star \star}$ & $24.32^{\star \star}$ & $46.70^{\star \star}$ \\
\hline SCA & 28 & & $1.03^{\star \star}$ & $1.08^{\star \star}$ & $1.66^{\star \star}$ & $60.66^{\star \star}$ & $61.17^{\star \star}$ & $115.1^{\star \star}$ & $0.09^{\star \star}$ & $0.08^{\star \star}$ & $0.14^{\star \star}$ & $28.86^{\star \star}$ & $22.31^{\star \star}$ & $40.01^{\star \star}$ \\
\hline GCA xEnv & & 7 & & & $1.002^{*}$ & & & 6.67 & & & $0.033^{*}$ & & & $6.55^{*}$ \\
\hline SCA xEnv & & 28 & & & $0.45^{\star *}$ & & & $6.69^{*}$ & & & $0.024^{\star *}$ & & & $11.16^{* *}$ \\
\hline Error & 70 & 140 & 0.18 & 0.18 & 0.18 & 3.57 & 3.65 & 3.61 & 0.005 & 0.008 & 0.006 & 2.13 & 1.43 & 1.78 \\
\hline GCA/SCA & & & 6.22 & 5.19 & 6.61 & 0.57 & 0.93 & 0.74 & 3.62 & 4.08 & 4.29 & 1.003 & 1.09 & 1.167 \\
\hline GCA x Env/GCA & & & & & 0.09 & & & 0.08 & & & 0.055 & & & 0.14 \\
\hline SCA x Env/SCA & & & & & 0.27 & & & 0.06 & & & 0.17 & & & 0.28 \\
\hline
\end{tabular}

${ }^{*}$ and ${ }^{\star \star}{ }^{*}$ indicate significant at 0.05 and 0.01 levels of probability, respectively. $\mathrm{N}=\mathrm{normal}, \mathrm{S}=\mathbf{s t r e s s}$ and Com.= combined 
Table (1): Mean square of ordinary analysis for relative water content, total soluble solids and flag leaf angle under normal and stress conditions as well as the combined data.

\begin{tabular}{|c|c|c|c|c|c|c|c|c|c|c|c|}
\hline \multirow{2}{*}{ S.0.V } & \multirow{2}{*}{ df } & \multirow{2}{*}{$\begin{array}{c}\text { df } \\
\text { Com }\end{array}$} & \multicolumn{3}{|c|}{ (\%)RWC } & \multicolumn{3}{|c|}{ TSS } & \multicolumn{3}{|c|}{ FLa } \\
\hline & & & $\mathbf{N}$ & $S$ & Com & $\mathbf{N}$ & $\mathbf{S}$ & Com. & $\mathbf{N}$ & $\mathbf{S}$ & Com \\
\hline Replication & 2 & & 0.23 & 1.92 & & 1.58 & 5.34 & & 21.53 & 0.30 & \\
\hline Environments & & 1 & & & $4179.76^{\star \star}$ & & & $350.12^{\star \star}$ & & & $10017.78^{\star \star}$ \\
\hline Rep.with environment & & 4 & & & 1.07 & & & 3.46 & & & 10.89 \\
\hline Genotypes & 35 & & $52.52^{\star \star}$ & $79.00^{* *}$ & $88.80^{\star *}$ & $2.50^{\star \star}$ & $3.76^{* *}$ & $4.88^{* \star}$ & $111.29^{* \star}$ & $24.57^{\star *}$ & $75.01^{* *}$ \\
\hline Parents & 7 & & $45.56^{* *}$ & $54.14^{\star *}$ & $39.463^{* *}$ & $3.98^{\star *}$ & $3.42^{*}$ & $7.00^{* *}$ & $55.80^{* *}$ & $9.41^{* *}$ & $25.76^{\star *}$ \\
\hline Crosses & 27 & & $55.62^{* \star}$ & $85.02^{\star *}$ & $101.41^{* *}$ & $2.20^{\star *}$ & $3.94^{* *}$ & $4.49^{*}$ & $123.35^{\star *}$ & $29.17^{\star \star}$ & $85.96^{* *}$ \\
\hline Pvs.C & 1 & & $17.44^{\star \star}$ & $90.46^{* *}$ & $93.67^{* \star}$ & 2. $24^{\star *}$ & $3.22^{* *}$ & $2.79^{* \star}$ & $174.05^{\star \star}$ & $6.61^{*}$ & $124.26^{* *}$ \\
\hline Genotypes x Env. & & 35 & & & $42.72^{\star *}$ & & & $1.37^{\star}$ & & & $60.85^{* *}$ \\
\hline Parents x Env. & & 7 & & & $60.23^{* *}$ & & & 0.40 & & & $39.45^{\star}$ \\
\hline Crosses x Env. & & 27 & & & $39.23^{* *}$ & & & $1.66^{*}$ & & & $66.56^{* *}$ \\
\hline P v s.C x Env. & & 1 & & & $14.23^{* \star}$ & & & 0.45 & & & $56.41^{\star *}$ \\
\hline Error & 70 & 140 & 3.62 & 6.28 & 4.95 & 0.66 & 0.90 & 0.73 & 17.04 & 3.16 & 10.10 \\
\hline GCA & 7 & & $46.81^{* *}$ & $29.16^{* *}$ & $59.03^{* *}$ & $1.32^{* *}$ & 0.34 & $1.38^{*}$ & $32.78^{*}$ & $11.25^{* *}$ & $28.20^{* *}$ \\
\hline SCA & 28 & & $10.18^{* *}$ & $25.63^{* *}$ & $22.24^{\star *}$ & $0.71^{* *}$ & $1.48^{\star *}$ & $1.69^{\star *}$ & $38.17^{\star \star}$ & $7.43^{* *}$ & $24.20^{* *}$ \\
\hline GCA xEnv & & 7 & & & $16.93^{* *}$ & & & 0.28 & & & $15.83^{*}$ \\
\hline SCA xEnv & & 28 & & & $13.57^{* \star}$ & & & $0.50^{*}$ & & & $21.38^{\star \star}$ \\
\hline Error & 70 & 140 & 1.21 & 2.09 & 1.65 & 0.22 & 0.33 & 0.28 & 5.68 & 1.06 & 3.37 \\
\hline GCA/SCA & & & 4.60 & 1.12 & 2.65 & 1.86 & 0.23 & 0.82 & 0.86 & 1.51 & 1.17 \\
\hline GCA x Env/GCA & & & & & 0.29 & & & 0.20 & & & 0.56 \\
\hline SCA $\times$ Env/SCA & & & & & 0.61 & & & 0.30 & & & 0.88 \\
\hline
\end{tabular}

(n) significant at 0.05 and 0.01 levels of probability, respectively. $\mathbf{N}=$ normal , $\mathrm{S}=$ stress , Com= combined kernel weight $=100-K W$ and grain yield/plant $=$ GY/P. 
J. Plant Prod., Mansoura Univ. Vol. 1 (11), November, 2010

Table (7): Genetic components of variation and proportions in diallel crosses for relative water content, total soluble solids, Flag leaf angle and number of spikes/plant under normal and stress conditions.

\begin{tabular}{|c|c|c|c|c|c|c|c|c|}
\hline \multirow{2}{*}{$\begin{array}{l}\text { Genetics } \\
\text { component }\end{array}$} & \multicolumn{2}{|c|}{ RWC (\%) } & \multicolumn{2}{|c|}{ TSS } & \multicolumn{2}{|c|}{ FLa } & \multicolumn{2}{|c|}{$\mathrm{NS} / \mathrm{p}$} \\
\hline & $\mathbf{N}$ & $\mathbf{S}$ & $\mathbf{N}$ & $\mathbf{S}$ & $\mathbf{N}$ & $\mathbf{S}$ & $\mathbf{N}$ & $\mathrm{S}$ \\
\hline${ }^{\circ} \mathrm{D}$ & $14.01^{\star *} \pm 3.57$ & $15.99^{\star *} \pm 5.73$ & $1.10^{* *} \pm 0.19$ & $0.77 \pm 0.69$ & $12.88 \pm 16.057$ & $2.11 \pm 5.42$ & $3.03^{* *} \pm 0.55$ & $2.47^{* *} \pm 0.55$ \\
\hline${ }^{n} \mathrm{H}_{1}$ & $45.49^{* *} \pm 8.21$ & $112.16^{* *} \pm 13.18$ & $2.57^{* *} \pm 0.43$ & $5.32^{* *} \pm 1.59$ & $138.67^{* *} \pm 36.91$ & $36.67^{* *} \pm 12.47$ & $5.62^{\star \star} \pm 1.27$ & $6.42^{* *} \pm 1.27$ \\
\hline${ }^{\wedge} \mathrm{H}_{2}$ & $39.17^{* *} \pm 7.14$ & $83.46^{\star \star} \pm 11.46$ & $2.14^{\star *} \pm 0.37$ & $4.60^{\star \star} \pm 0.93$ & $128.11^{* *} \pm 32.11$ & $31.49^{* *} \pm 10.85$ & $3.83^{\star \star} \pm 1.11$ & $4.77^{* \star} \pm 1.10$ \\
\hline${ }^{\wedge} h^{2}$ & $2.35 \pm 4.79$ & \begin{tabular}{|l|}
$13.94 \pm 7.69$ \\
\end{tabular} & $-0.10 \pm 0.25$ & $0.04 \pm 0.93$ & $26.05 \pm 21.54$ & $0.64 \pm 7.28$ & $0.75 \pm 0.74$ & $1.39 \pm 0.74$ \\
\hline${ }^{\wedge} \mathrm{F}$ & $1.60 \pm 8.44$ & $28.61^{*} \pm 13.54$ & $1.13^{*} \pm 0.44$ & $1.42 \pm 1.63$ & $8.38 \pm 37.94$ & $4.69 \pm 12.82$ & $2.56^{*} \pm 1.31$ & $2.56^{\star} \pm 1.30$ \\
\hline${ }^{n} \mathrm{E}$ & $1.18 \pm 1.19$ & $2.05 \pm 1.91$ & $0.23^{* \star} \pm 0.06$ & $0.37 \pm 0.23$ & $5.72 \pm 5.35$ & $1.03 \pm 1.81$ & $0.19 \pm 0.18$ & $0.19 \pm 0.18$ \\
\hline$(\mathrm{H} 1 / \mathrm{D})^{1 / 2}$ & 1.80 & 2.65 & 1.53 & 2.63 & 3.28 & 4.17 & 1.36 & 1.61 \\
\hline $\mathrm{H}_{2} / 4 \mathrm{H}_{1}$ & 0.22 & 0.19 & 0.21 & 0.22 & 0.23 & 0.21 & 0.17 & 0.19 \\
\hline KD/KR & 1.07 & 2.02 & 2.02 & 2.08 & 1.22 & 1.73 & 1.90 & 1.95 \\
\hline$h^{2} / H_{2}$ & 0.06 & 0.17 & -0.05 & 0.01 & 0.20 & 0.02 & 0.20 & 0.29 \\
\hline Heritability & 0.46 & 0.26 & 0.20 & 0.02 & 0.17 & 0.13 & 0.50 & 0.36 \\
\hline$r$ & 0.12 & $-0.74^{\star *}$ & $0.55^{\star *}$ & $-0.61^{* *}$ & $-0.65^{\star *}$ & $-0.57^{* *}$ & $0.80^{\star *}$ & $0.54^{\star *}$ \\
\hline $\mathbf{R}^{2}$ & 0.01 & 0.54 & 0.30 & 0.37 & 0.42 & 0.32 & 0.64 & 0.29 \\
\hline
\end{tabular}

${ }^{\star}$ and ${ }^{\star \star}$ indicate significant at 0.05 and 0.01 levels of probability, respectively $\mathrm{N}=$ normal and $\mathrm{S}=$ stress 